\title{
The human ovarian cancer cell line CABA I: A peculiar genetic evolution
}

\author{
ILARIA GIUSTI $^{1}$, CARLA CERVELLI ${ }^{2}$, SANDRA D'ASCENZO ${ }^{1}$, MARIANNA DI FRANCESCO ${ }^{1}$, \\ CLAUDIO LIGAS $^{1}$, ELVIRA D'ALESSANDRO ${ }^{1}$, FRANCO PAPOLA $^{2}$ and VINCENZA DOLO ${ }^{1}$ \\ ${ }^{1}$ Department of Life, Health and Environmental Sciences, University of L'Aquila; \\ ${ }^{2}$ Regional Center of Immunohematology and Tissue Typing, L'Aquila, Italy
}

Received July 23, 2015; Accepted December 22, 2015

DOI: $10.3892 / \mathrm{ijmm} .2016 .2501$

\begin{abstract}
The objective of this study was to study the human ovarian cancer cell line CABA I by means of short tandem repeats (STR) profiling and cytogenetic analysis in order to prevent future misidentification or cross-contamination and verify its stability during in vitro cultivation. To this end, cells at passages 18 and 38 were analyzed using cytogenetic techniques in order to verify possible chromosomal aberrations and the karyotypic evolution of this cell line; GTG-banding and FISH were also performed. For STR analysis, DNA was extracted using the automated extractor MagNA pure and analyzed by means of PowerPlex 16 HS. STR profiles were analyzed by GeneMapper 3.2.1 software. Whereas comparative cytogenetic analysis of CABA I cells at passage 18 and 38 has demonstrated considerable genetic instability, we found that STR profiles were essentially unaltered in both analyzed passages, suggesting that the STR profile is reliable and could be used for the regular authentication of CABA I over time. It should be emphasized, however, that of the 16 loci generally used in human STR profiles, only 3 were properly detectable in CABA I. The data highlight that the CABA I cell line demonstrates an anomalous STR profile that does not fully adjust the criteria currently used for the identification of human cells; in spite of this, it remains stable during the in vitro maintainance. Moreover, the genetic instability of the CABA I cell line overlaps with those observed in vivo in tumor cells, making it a suitable candidate to analyze, in vitro, the peculiar genetic evolution of ovarian cancer cells.
\end{abstract}

\section{Introduction}

Ovarian cancer, which comprises a heterogeneous group of neoplasms, is the most lethal gynecological malignancy (1).

Correspondence to: Professor Vincenza Dolo, Department of Life, Health and Environmental Sciences, University of L'Aquila, Via Vetoio-Coppito 2, I-67100 L'Aquila, Italy

E-mail: vincenza.dolo@univaq.it

Key words: ovarian cancer, short tandem repeat profile, CABA I cell line
It is characterized by poor prognosis, with an overall 5-year survival rate of approximately $50 \%$ that, however, rises to $90 \%$ if the cancer is diagnosed while still confined to the ovary (an event that, unfortunately, occurs in $20 \%$ of patients) (2).

Ovarian cancer diagnosis, indeed, is often delayed since this pathology lacks specific symptoms (non-specific symptoms include frequent urination, bloating, abdominal fullness and early satiety) which, instead, appear only during advanced stages and are related to the presence of large tumors or extensive ascites (3). Tools for ovarian cancer diagnosis include computer tomography-positron emission tomography (CT-PET), fluorodeoxyglucose-PET (FDG-PET), magnetic resonance, transvaginal and transabdominal sonography, as well as serum marker CA-125 measurement (2). An early diagnosis provides patients with a greater chance of being properly cured using the available therapies (such as surgery or chemotherapy with a combination of platinum and taxane); the more a tumoral mass is reduced by surgery, the more often chemotherapy is effective (4).

Many studies regarding different pathologies, as well as cancer diseases, rely on in vitro cell line research; specifically, ovarian cancer studies may use several human cell lines such as OVCAR3 (5), SK-OV-3 (6), A2780 (7), IGROV1 (8) or OAW42 (9). CABA I is an ovarian cancer cell line of epithelial origin, which was established from ascitic fluid obtained from a patient with papillary adenocarcinoma of the ovary prior to drug treatment. CABA I cell growth is anchorage dependent and very rapid (the doubling time is approximately $18 \mathrm{~h}$ ); preliminary cytogenetic analysis indicated a modal chromosome number of 57-58, with 44 clonal structural aberrations and only few chromosomes appearing morphologically normal (10).

It has previously been demonstrated that growth and phenotypic characteristics are maintained both in early and late passages, suggesting that the CABA I cell line provides a suitable in vitro model system in order to investigate the cellular and molecular events involved in ovarian carcinogenesis (10). Thus, since then, many studies have concentrated on CABA I behavior in cancer progression, with particular interest being shown in relation to the release of extracellular vesicles (11-18).

For some years, the short tandem repeats (STR) profiling has been the international reference standard for the identification of cell lines (19-22), and thus in the present study we proceeded to subject CABA I to this analysis to prevent 
future misidentification or cross-contaminations during in vitro cultivation. Furthermore, the cell line was analyzed by classical and molecular cytogenetic techniques: we chose two different passages, the 18th and 38th, to identify chromosomal aberrations and the karyotypic evolution of this cell line.

\section{Materials and methods}

CABA I cells. The 18th and 38th passages of CABA I cells were grown as monolayers in RPMI-1640 with 5\% fetal calf serum, $2 \mathrm{mM}$ glutamine and penicillin $100 \mathrm{U} / \mathrm{ml}$ (all materials are from Euroclone, Devon, UK). Cells at passages 18 and 38 were tested for mycoplasma infection and the result was negative. Cells passed from 18th to 38th passages in approximately 15 weeks.

Cytogenetic analyses. Standard cytogenetic techniques (23) were used on CABA I cells at the 18th and 38th passages in order to identify chromosomal aberrations and the karyotypic evolution of this cell line.

In addition, every metaphase was analyzed by sequential GTG-banding and fluorescence in situ hybridization (FISH) with whole chromosome painting probes specific for each chromosome. Briefly, metaphases stained with giemsa solution after partial trypsin digestion (GTG-banding) were observed under a light field microscope (Leica Aristoplan microscope; Leica, Wetzlar, Germany), captured with PSI MacKtype software and finally destained three times in methanol. The slides were then washed in $2 \mathrm{X} \mathrm{SSC}$ solution, heated at $70^{\circ} \mathrm{C}$ in SSC/ formamide solution to denature target chromosome DNA, and hybridized with FISH probes specific to a whole chromosome. Observation under a fluorescence microscope allowed us to capture again the same GTG-banded metaphases previously observed and analyze the hybridization on markers chromosomes of the CABA I cell line.

DNA extraction. The DNA contained in CABA I cells, at the 18th and 38th passages, was extracted from approximately $5 \times 10^{6}$ cells using an automatic extractor MagNA Pure Compact system (Roche Diagnostics, Basel, Switzerland). The procedure involves several steps, consisting of preparatory cell disruption and protein digestion caused by the addition of lysis buffer and proteinase $\mathrm{K}$, the formation of nucleic acid-bead complexes caused by nucleic acid binding to the surface of magnetic glass particles and subsequent magnetic separation; after washing to remove cell debris, nucleic acid is eluted at high temperatures with simultaneous removal of the magnetic glass particles. Thus, 44.4 and $136 \mathrm{ng} / \mu 1$ were obtained from CABA I 18th and 38th passages, respectively.

STR analysis. An amplification PCR kit PowerPlex ${ }^{\circledR} 16$ HS (Promega, Fitchburg, WI, USA) is a multiplex STR test that co-amplifies in a single polymerase chain reaction (PCR) 16 loci: D18S51, D21S11, TH01, D3S1358, FGA, TPOX, D8S1179, vWA, CSF1PO, D16S539, D7S820, D13S317, D5S818, Amelogenin, Penta E and Penta D. Table I includes specific information for each locus. The kit also contains an allelic ladder, which is a mix of more common alleles for each analyzed locus: the genotype is assigned by means of comparing dimensions of unknown samples and the aforementioned allelic ladder. The kit requires only $0.5-1 \mathrm{ng}$ of DNA for
Table I. Summary information of GenePrint ${ }^{\circledR}$ PowerPlex 16 System-loci.

\begin{tabular}{lclc}
\hline STR locus & $\begin{array}{c}\text { Chromosomal } \\
\text { location }\end{array}$ & $\begin{array}{c}\text { Repeat } \\
\text { sequence } \\
5^{\prime} \rightarrow 3^{\prime}\end{array}$ & $\begin{array}{c}\text { Size } \\
\text { range } \\
\text { (bases) }\end{array}$ \\
\hline Penta E & $15 \mathrm{q}$ & AAAGA & $379-474$ \\
D18S51 & $18 \mathrm{q} 21.3$ & AGAA & $290-366$ \\
D21S11 & $21 \mathrm{q} 11-21 \mathrm{q} 21$ & TCTA & $203-259$ \\
TH01 & $11 \mathrm{p} 15.5$ & AATG & $156-195$ \\
D3S1358 & $3 \mathrm{p}$ & TCTA & $115-147$ \\
FGA & 4q28 & TTTC & $322-444$ \\
TPOX & 2p23-2pter & AATG & $262-290$ \\
D8S1179 & $8 \mathrm{q}$ & TCTA & $203-247$ \\
vWA & $12 \mathrm{p} 12-\mathrm{pter}$ & TCTA & $123-171$ \\
Amelogenin & Xp22.1-22.3 & Not & 106,112 \\
& and $\mathrm{Y}$ & applicable & \\
Penta D & $21 \mathrm{q}$ & AAAGA & $376-441$ \\
CSF1PO & $5 \mathrm{q} 33.3-34$ & AGAT & $321-357$ \\
D16S539 & $16 \mathrm{q} 24-\mathrm{qter}$ & GATA & $264-304$ \\
D7S820 & $7 \mathrm{q} 11.21-22$ & GATA & $215-247$ \\
D13S317 & $13 \mathrm{q} 22-\mathrm{q} 31$ & TATC & $169-201$ \\
D5S818 & 5q23.3-32 & AGAT & $119-155$ \\
\hline
\end{tabular}

STR, short tandem repeats. The Geneprint PowerPlex 16 System user manual is available at http://www.cstl.nist.gov/strbase/images/powerplex16.pdf.

a single test. The obtained DNA fragments are automatically analyzed by a triple fluorescence system.

In order to perform PCR, according to the manufacturer's instructions, DNA was diluted to a final concentration of $0.5 \mathrm{ng} / \mu \mathrm{l}$. PCR tubes were prepared, mixing all components suggested in adequate volumes: DNA template $(0.5-1 \mathrm{ng})$, PowerPlex HS Master Mix, PowerPlex 16 HS Primer Pair Mix and water (amplification grade). Each amplification, aside from samples, also contains positive and negative controls (provided in kit). Amplification was performed, as suggested, using the thermal cycler GeneAmp PCR system 9700 (Thermo Fisher Scientific, Waltham, MA, USA) and the following cycles: $96^{\circ} \mathrm{C}$ for $2 \mathrm{~min}$, then ramp $100 \%$ to $94^{\circ} \mathrm{C}$ for $30 \mathrm{sec}-\operatorname{ramp} 29 \%$ to $60^{\circ} \mathrm{C}$ for $30 \mathrm{sec}-$ ramp $23 \%$ to $70^{\circ} \mathrm{C}$ for 45 seconds for a total of 10 cycles, then ramp $100 \%$ to $90^{\circ} \mathrm{C}$ for $30 \mathrm{sec}$ - ramp $29 \%$ to $60^{\circ} \mathrm{C}$ for $30 \mathrm{sec}-\operatorname{ramp} 23 \%$ to $70^{\circ} \mathrm{C}$ for 45 seconds for a total of 22 cycles, then $60^{\circ} \mathrm{C}$ for $30 \mathrm{~min}$ and finally a $4^{\circ} \mathrm{C}$ soak.

One microliter of amplified DNA was combined with $10 \mu \mathrm{l}$ mix solution $(9.5 \mu 1$ formamide and $0.5 \mu 1$ IL600 Standard; Promega). Simultaneously, in the appropriate well, $1 \mu \mathrm{l}$ allelic ladder was distributed. Samples were heat denatured at $95^{\circ} \mathrm{C}$ for $3 \mathrm{~min}$, quickly refrigerated on ice for at least $3 \mathrm{~min}$, transferred onto a plate and placed in the ABI 3130 sequencer (Applied Biosystems Life Technologies, Foster City, CA, USA) with POP7 polymer (a separation matrix for performing DNA sequencing and fragment analysis) in a 36- $\mathrm{cm}$ capillary tube. ABI 3130 was set for an electrophoresis run and, subsequently, STR profiles were analyzed by Software GeneMapper 3.2.1. 


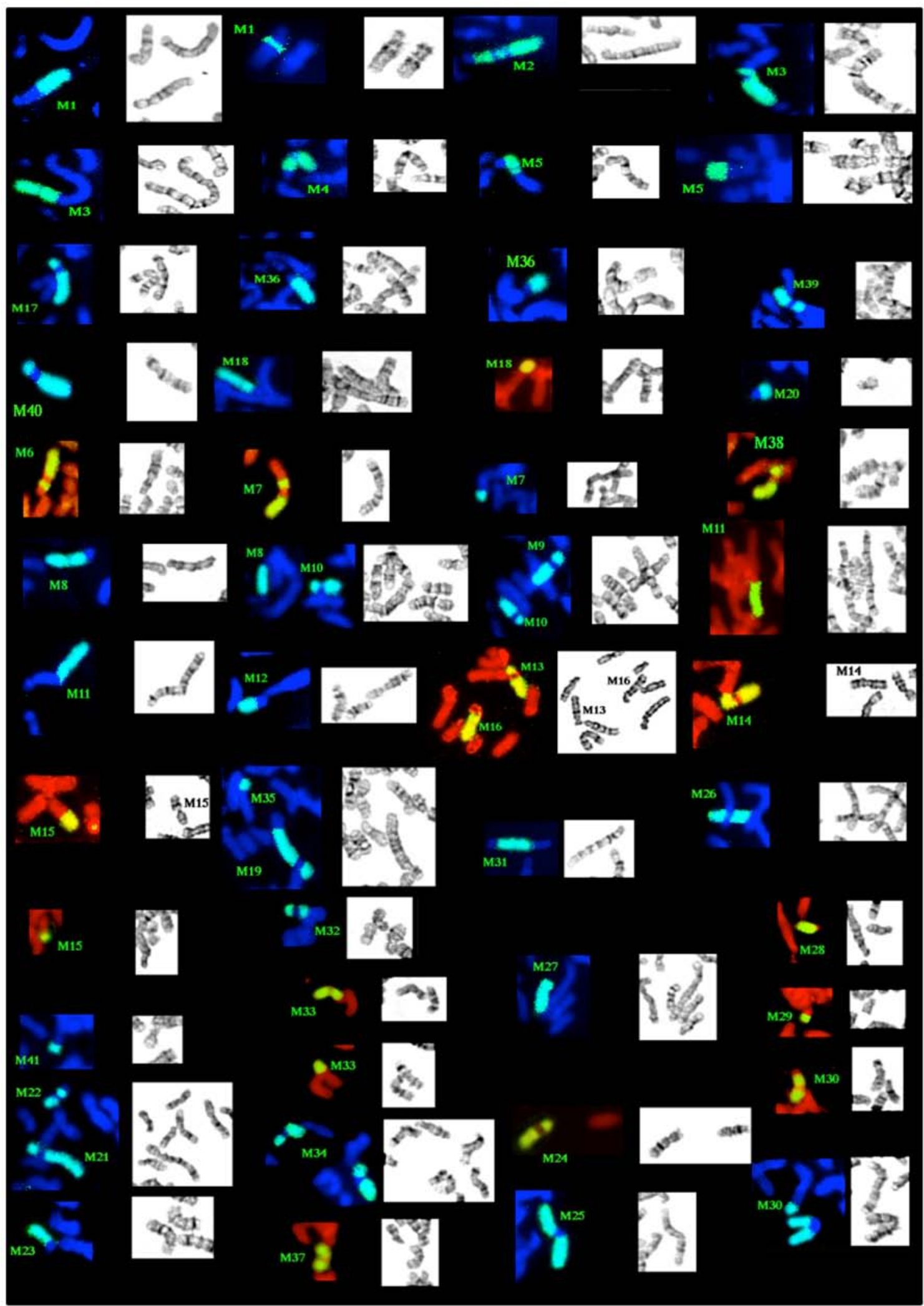

Figure 1. Karyotype of CABA I cells at the 18th passage.

\section{Results}

Cytogenetic analysis. After cytogenetic analysis of the 18 th passage, we noted a highly complex karyotype with a modal number of 57-58 chromosomes, 44 clonal markers and a chromosomal instability which was represented by frequent sporadic aberrations (Fig. 1). We also noted that eight of the clonal markers are present in duplicate. The description of the structural aberrations is reported in Table II. Certain chromosomal regions, such as 7p11-13, 15q11-15 and 17p11-13 seemed to be over represented, while others, i.e., $6 \mathrm{q} 25-27,9 \mathrm{p}$ and $15 \mathrm{q} 24$-qter were lost. 
Table II. Description and frequency of chromosomal markers.

\begin{tabular}{|c|c|c|}
\hline Marker & Description & $\%$ \\
\hline M1 & $\operatorname{der}(9) \mathrm{t}(1 ; 9)(\mathrm{p} 13.3 ; \mathrm{p} 21.2) \operatorname{del}(9)(\mathrm{q} 21.2)$ & 100 \\
\hline M2 & $\operatorname{del}(1)(\mathrm{q} 11)$ & 100 \\
\hline M3 & $\operatorname{der}(4) t(1 ; 4)(q 12 ; p 12) \operatorname{inv}(4)(p 12 q 21)$ & 100 \\
\hline M4 & $\operatorname{der}(?) \mathrm{t}(1 ; ?)(\mathrm{q} 21 ; ?)$ & 100 \\
\hline M5 & $\operatorname{der}(1) \mathrm{t}(1 ; 9)(\mathrm{p} 22 ; \mathrm{q} 13) \operatorname{del}(1)(\mathrm{q} 11)$ & 100 \\
\hline M6 & $\operatorname{der}(?) \mathrm{t}(2 ; ? ; 2)(\mathrm{q} 21 ; ? ; ?)(\mathbf{x} 2)$ & 100 \\
\hline M7 & $\operatorname{der}(2) \mathrm{t}(2 ; 8)(\mathrm{q} 14.2 ; \mathrm{q} 13)$ & 100 \\
\hline M8 & $\operatorname{der}(3) \mathrm{t}(3 ; ?)(\mathrm{q} 25 ; ?) \operatorname{inv}(3)(\mathrm{p} 21 \mathrm{q} 25)$ & 100 \\
\hline M9 & $\operatorname{del}(3)(\mathrm{p} 14)$ & 100 \\
\hline M10 & $\operatorname{der}(3) ?(\mathbf{x} 2)$ & 100 \\
\hline M11 & $\operatorname{der}(14) t(4 ; 14)(q 13.2 ; p 11)$ & 100 \\
\hline M12 & $\operatorname{del}(4)(q 12)$ & 100 \\
\hline M13 & $\operatorname{inv}(5)(\mathrm{p} 15 \mathrm{q} 13) \operatorname{del}(5)(\mathrm{q} 13)$ & 100 \\
\hline M14 & $\operatorname{del}(5)(q 15)$ & 100 \\
\hline M15 & $\operatorname{der}(15) \mathrm{t}(5 ; 15)(\mathrm{p} 13 ; \mathrm{p} 12) \operatorname{del}(15)(\mathrm{q} 13)$ & 100 \\
\hline M16 & $\operatorname{der}(?) \mathrm{t}(5 ; ?)(\mathrm{q} 15 ; ?)(\mathbf{x} 2)$ & 100 \\
\hline M17 & $\operatorname{del}(6)(\mathrm{q} 25.1) \operatorname{del}(6)(\mathrm{p} 21.1) \operatorname{inv}(6)(\mathrm{q} 25.1 \mathrm{q} 11)$ & 100 \\
\hline M18 & $\begin{array}{c}\operatorname{der}(7) \mathrm{t}(7 ; 16)(\mathrm{p} 22 ; \mathrm{p} 11) \operatorname{inv}(7)(\mathrm{q} 11 \mathrm{p} 22) \\
\operatorname{inv}(7)(\mathrm{q} 11 \mathrm{q} 32)\end{array}$ & 100 \\
\hline M19 & $\operatorname{inv}(7)(p 22 q 21)$ & 100 \\
\hline M20 & $\operatorname{del}(7)(\mathrm{p} 15) \operatorname{del}(7)(\mathrm{q} 11.2)$ & 100 \\
\hline M21 & $\operatorname{dup}(8)(q 21 \mathrm{qter})$ & 57 \\
\hline M22 & $\operatorname{del}(8)(\mathrm{q} 11 \mathrm{q} 22)$ & 100 \\
\hline M23 & $\operatorname{der}(19) t(9 ; ? ; 19)(q 13 ; ? ; q 11$ o p11) & 100 \\
\hline M24 & $\operatorname{inv}(10)(\mathrm{q} 21.2 \mathrm{q} 23.2)(\mathbf{x} 2)$ & 100 \\
\hline M25 & $\operatorname{inv}(11)(\mathrm{p} 11.2 \mathrm{q} 13.3)(\mathbf{x} 2)$ & 100 \\
\hline M26 & $\operatorname{inv}(13)(p 12 q 21.2) \operatorname{inv}(13)(q 12 q 21.2)$ & 100 \\
\hline M27 il & $\operatorname{inv}(13)(\mathrm{p} 12 \mathrm{q} 21.2) \operatorname{inv}(13)(\mathrm{q} 12 \mathrm{q} 21.2) \operatorname{del}(13)(\mathrm{q} 14)$ & 100 \\
\hline M28 & $\operatorname{del}(15)(q 24) \operatorname{inv}(15)(q 11.2 q 24)(\mathbf{x} 2)$ & 100 \\
\hline M29 & $\operatorname{del}(15)(\mathrm{q} 15)$ & 100 \\
\hline M30 & $\operatorname{der}(16) t(X ; 16)(? ; p 13)$ & 100 \\
\hline M31 & $\operatorname{der}(?) \mathrm{t}(? ; 17)(? ; \mathrm{q} 21)$ & 30 \\
\hline M32 & $\mathrm{i}(17 \mathrm{p})$ & 30 \\
\hline M33 & $\begin{array}{c}\operatorname{der}(20) \mathrm{t}(20 ; 21)(\mathrm{p} 13.1 ; \mathrm{q} 11) \\
\operatorname{inv}(20)(\mathrm{p} 13.1 \mathrm{q} 13.1) \operatorname{inv}(21)(\mathrm{q} 11 \mathrm{q} 22.3)(\mathbf{x} 2)\end{array}$ & 100 \\
\hline M34 & $\operatorname{inv}(18)(\mathrm{p} 11.3 \mathrm{q} 21.3) \operatorname{inv}(18)(\mathrm{q} 11.2 \mathrm{q} 21.3)(\mathbf{x} 2)$ & 100 \\
\hline M35 & $\operatorname{der}(7) \mathrm{t}(7 ; 22)(\mathrm{q} 11 ; \mathrm{q} 11) \operatorname{del}(7)(\mathrm{p} 15)$ & 100 \\
\hline M36 & $\operatorname{der}(?) \mathrm{t}(6 ; 22 ; ?)(\mathrm{q} 15 ; \mathrm{q} 11.2 ; ?) \operatorname{del}(6)(\mathrm{q} 25.1)$ & 100 \\
\hline M37 & $\operatorname{del}(16)(\mathrm{q} 21)$ & 100 \\
\hline M38 & $\operatorname{del}(2)(q 21)$ & 100 \\
\hline M39 & $\operatorname{del}(6)(\mathrm{p} 22.2) \operatorname{del}(6)(\mathrm{q} 13)$ & 100 \\
\hline M40 & $\operatorname{del}(6)(\mathrm{q} 13)$ & 100 \\
\hline M41 & $\operatorname{del}(7)(\mathrm{p} 15) \operatorname{del}(7)(\mathrm{q} 11)$ & 100 \\
\hline M42 & $\operatorname{der}(\mathrm{X})$ & 100 \\
\hline M43 & $\operatorname{der}(X) t(X ; 12)(q 27 ; q 12)$ & 40 \\
\hline M44 & $\mathrm{t}(\mathrm{M} 31 ; ?)$ & 70 \\
\hline
\end{tabular}

Eight of the clonal markers are present in duplicate (presented in bold).

Studying the cells at the 38th passage provided some interesting evolutionary changes in the complex karyotype

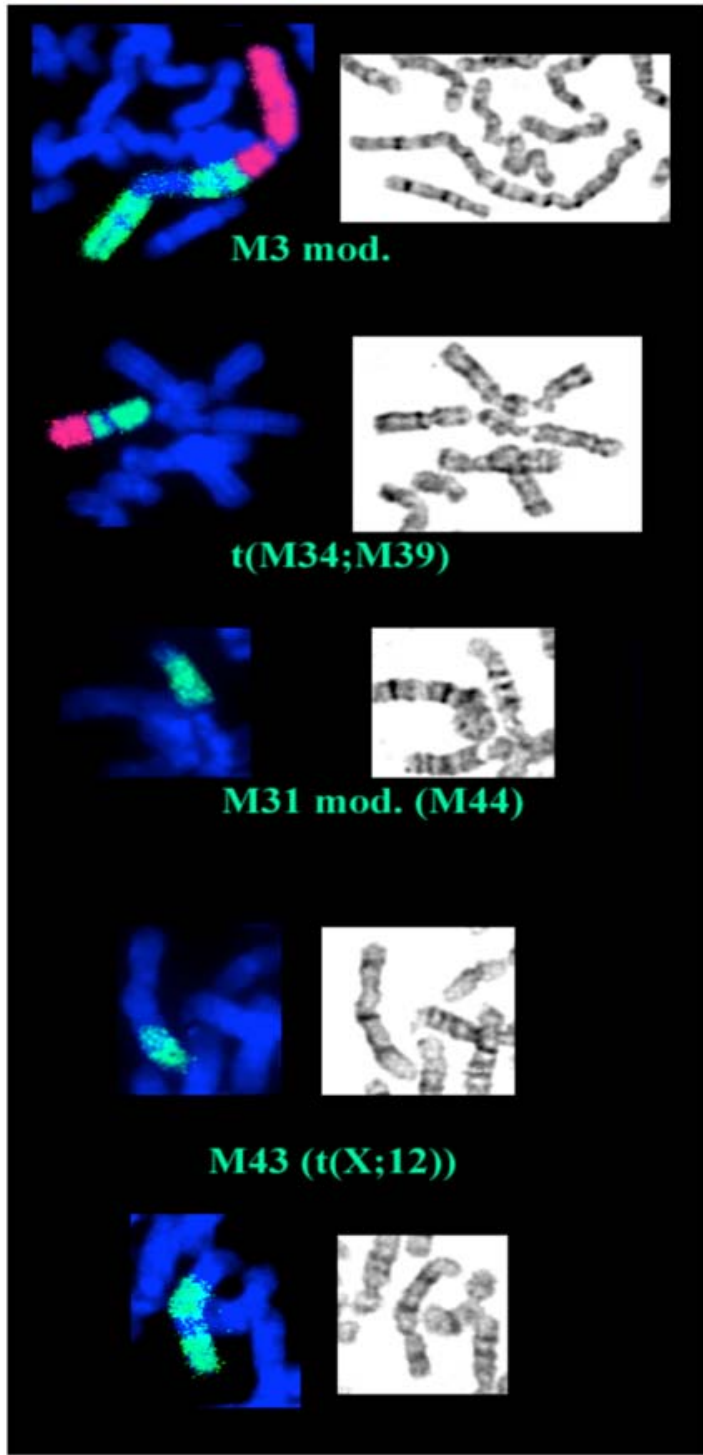

Figure 2. Karyotype of CABA I cells at the 38th passage: the figure depicts the markers modified in the 38 th passage.

regarding both the structure and frequency of previous identified markers, as shown in Table III: namely, markers M3, one copy of M34 and M39 have undergone further rearrangements, M43 and M44 (a rearrangement of M31) have modified their frequency (increasing up to 100\%), while M31, M32 and M41 are definitely lost, leading to a modal number of 55 (Fig. 2). The chromosomal regions lost or gained in 18th and 38th passages are depicted in Fig. 3.

STR profiles. Fig. 4 depicts the complete STR profile for CABA I cells at 18th (Fig. 4A) and 38th (Fig. 4B) passages. Fig. 5 depicts a typical human male and female STR profile (Fig. 5A and B, respectively), including all the peaks the kit was able to identify. A comparison of Figs. 4 and 5 highlights the fact that only 3 alleles are properly detected in both CABA I samples. Amelogenin marker is present, confirming that CABA I are cells from a female, as well as D7-10 and FGA-28.2 STR alleles. The kit also identified alleles belonging to PENTA E and CS1PO loci; even though they were not placed exactly in the used allelic ladder (and thus 
Table III. Cytogenetic changes between the 18th and 38th passage in the CABA I cell line.

\begin{tabular}{|c|c|c|c|}
\hline \multirow[b]{2}{*}{ Marker } & \multirow[b]{2}{*}{ Description of marker } & \multicolumn{2}{|c|}{ Frequency at } \\
\hline & & 18th passage & 38th passage \\
\hline Modal no. & - & 57 & 55 \\
\hline M3 & $\operatorname{der}(4) \mathrm{t}(1 ; 4)(\mathrm{q} 12 ; \mathrm{p} 12) \operatorname{inv}(4)(\mathrm{p} 12 \mathrm{q} 21)$ & $100 \%$ & $5 \%$ \\
\hline M3 mod & $\operatorname{invdup}(1)(\mathrm{q} 12 \mathrm{q} 32) \operatorname{der}(4) \mathrm{t}(1 ; 4)(\mathrm{q} 12 ; \mathrm{p} 12) \operatorname{inv}(4)(\mathrm{p} 12 \mathrm{q} 21)$ & $0 \%$ & $95 \%$ \\
\hline M21 & $\operatorname{dup}(8)(q 21 q t e r)$ & $57 \%$ & $40 \%$ \\
\hline 8 & normal & $43 \%$ & $60 \%$ \\
\hline M31 & $\operatorname{der}(?) \mathrm{t}(? ; 17)(? ; \mathrm{q} 21)$ & $30 \%$ & $0 \%$ \\
\hline M31 mod. (M44) & $\operatorname{der}(?) t(? ; 17 ; ?)(? ; q 21 ; ?)$ & $70 \%$ & $100 \%$ \\
\hline M32 & $\mathrm{i}(17 \mathrm{p})$ & $30 \%$ & $0 \%$ \\
\hline M34 (1 copy) & $\operatorname{inv}(18)(\mathrm{p} 11.3 \mathrm{q} 21.3) \operatorname{inv}(18)(\mathrm{q} 11.2 \mathrm{q} 21.3)$ & $100 \%$ & $0 \%$ \\
\hline M34 mod. & der(M39)t(M34;M39) & $0 \%$ & $100 \%$ \\
\hline M39 & $\operatorname{del}(6)(\mathrm{p} 22.2) \operatorname{del}(6)(\mathrm{q} 13)$ & $100 \%$ & $0 \%$ \\
\hline M41 & $\operatorname{del}(7)(\mathrm{p} 15) \operatorname{del}(7)(\mathrm{q} 11)$ & $100 \%$ & $0 \%$ \\
\hline M43 & $\operatorname{der}(X) t(X ; 12)(q 27 ; q 12)$ & $40 \%$ & $100 \%$ \\
\hline
\end{tabular}

Table IV. STR changes between the18th and 38th passages in the CABA I cell line.

\begin{tabular}{lcc}
\hline PowerPlex 16 HS & 18th passage & 38th passage \\
\hline D3 & 16 & - \\
Penta E & OL (between & OL (between \\
& alleles 6 and 7) & alleles 6 and 7) \\
CS1PO & OL (between & OL (between \\
& alleles 13 and 14) & alleles 13 and 14) \\
Amelogenin & $\mathrm{X}$ & $\mathrm{X}$ \\
D7 & 10 & 10 \\
FGA & 28.2 & 28.2 \\
\hline
\end{tabular}

STR, short tandem repeat.

were not tagged by software as off ladder) they maintained a steady position (detailed in Fig. 6). A summary of the obtained results is reported in Table IV.

\section{Discussion}

The use of cell lines is a pivotal tool in biological research; to prevent drawbacks such as invalidated results and wasting years of work, it is fundamental to avoid the use of misidentified or cross-contaminated cell lines $(24,25)$. The identification of cell lines has been performed, over the years, using several strategies, ranging from isoenzyme analysis (it is possible to identify cell lines by analyzing isoenzyme electrophoresis profiles and comparing migration patterns with specific and known controls) $(26,27)$, immunophenotypic and immunocytochemical analysis (identification of certain markers could help in the characterization of the histological origin of cell lines) $(28,29)$, human leukocyte antigen (HLA) typing (27), cytogenetic analysis (30) to DNA fingerprinting (cells are identified by their specific DNA profile) $(31,32)$.

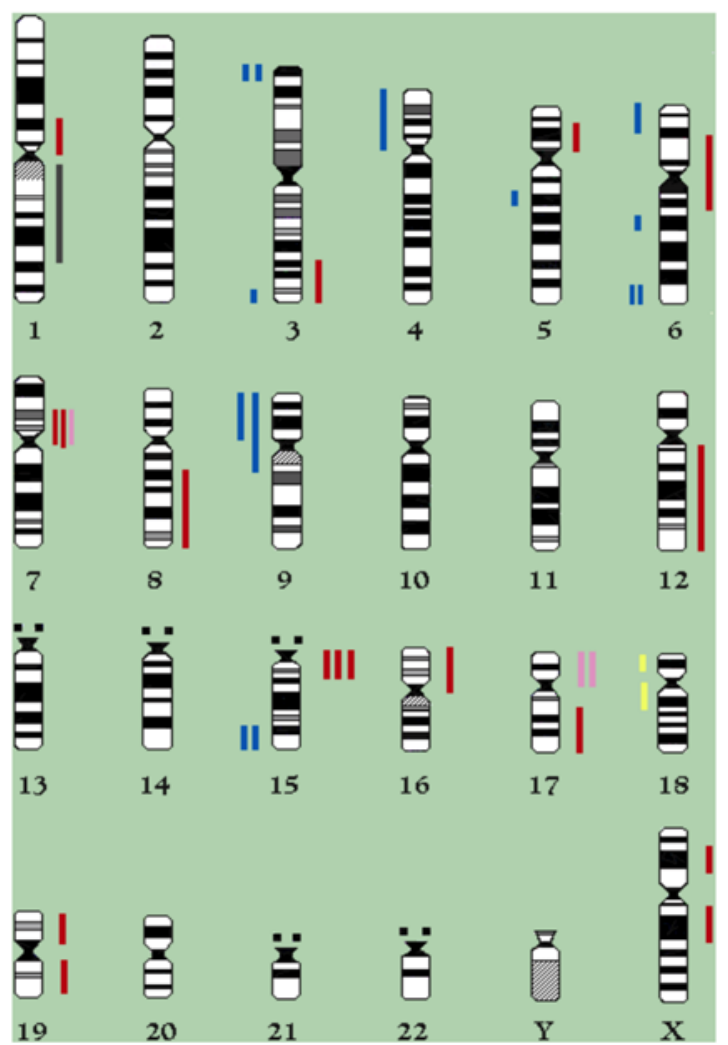

Figure 3. Chromosomal regions lost or gained in the 18th and 38th passages: red denotes gains in 18th and 38th passages, blue denotes losses in 18th and 38th passages, pink denotes gains in 18th passage, yellow denotes losses in 38 th passage, and black denotes gains in 38th passage.

DNA profiling techniques take advantage of specific genetic differences between individuals in DNA variable loci (32) and are based on DNA amplification by PCR; these techniques take into account both directed amplification of minisatellite-region DNA (DAMD) and the variable number of tandem repeats (VNTR), which are highly specific to each 


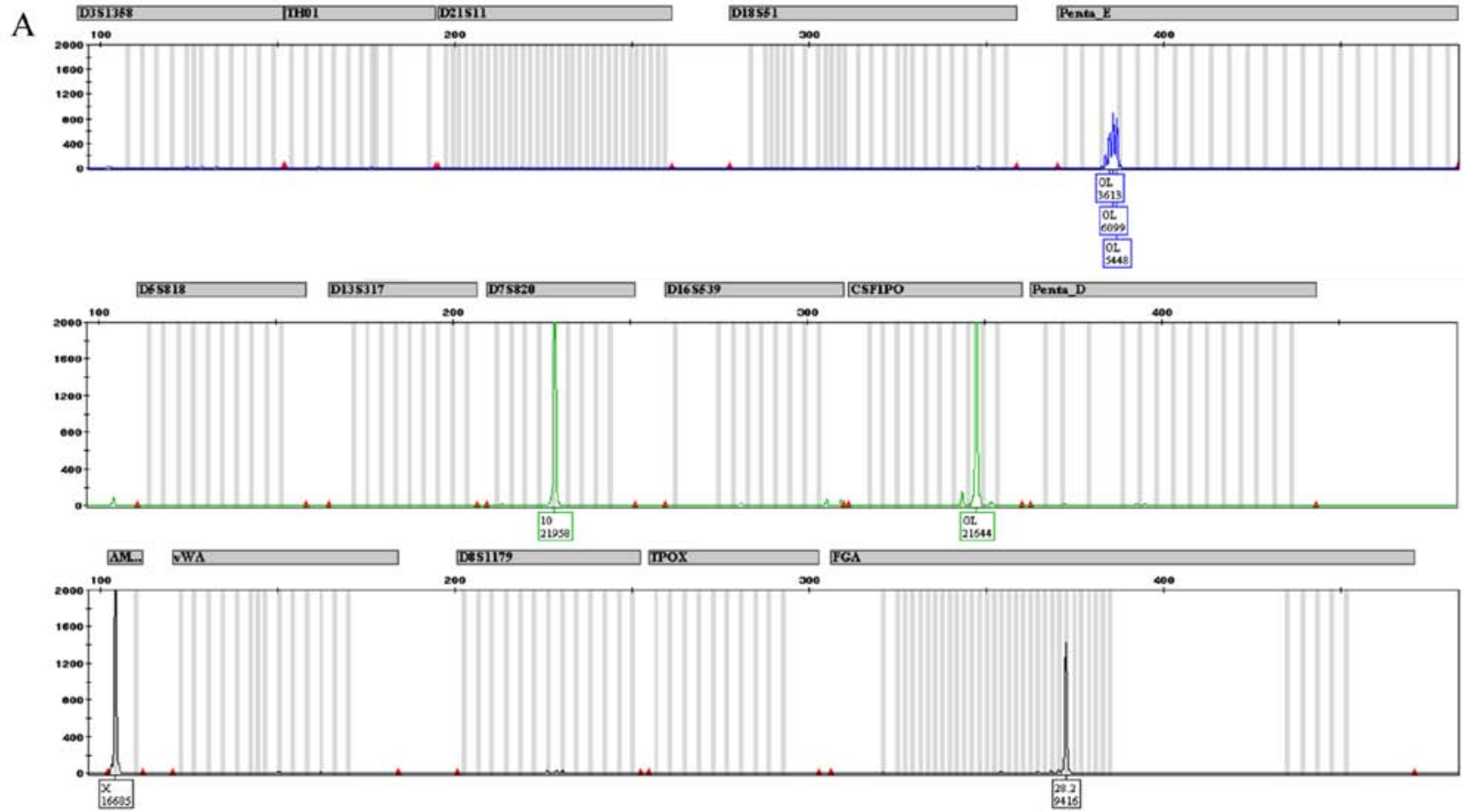

B
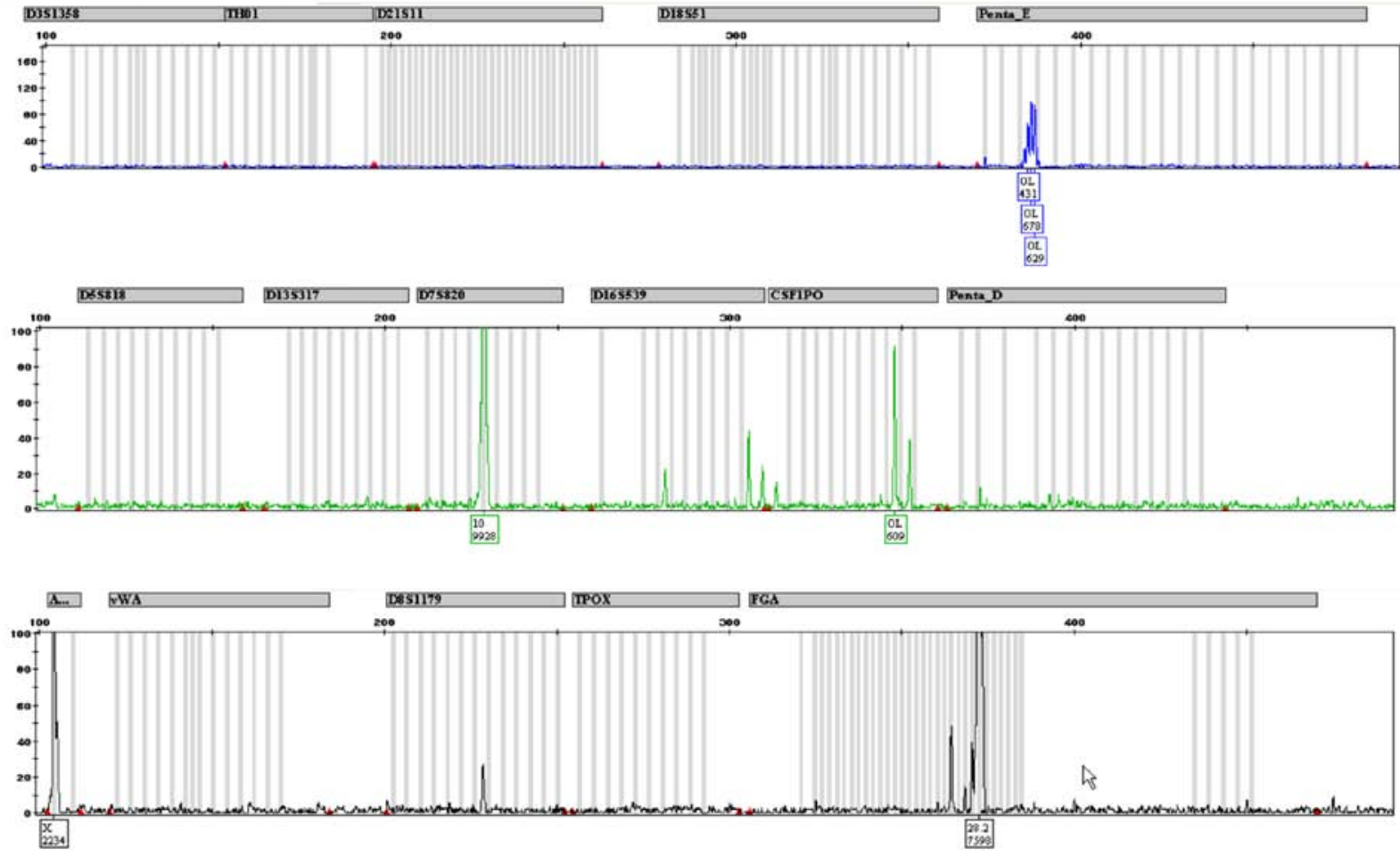

Figure 4. CABA I STR profile: short tandem repeat (STR) profile of CABA I cells at 18th (A) and 38th (B) passages.

individual (33). The high level of progress of technology in this field led, eventually, to the development of STR analysis $(19,25)$.

STRs, also known as SSRs (simple sequence repeats) or microsatellites, are short sequences of non-coding DNA of 2-7 base pairs, which are repeated as di-, tri- or tetra-nucleotide tracts (34); they account for approximately $3 \%$ of total DNA and are thought to play a role in the chromosome structure. They are used as molecular markers of specific loci of the genome; indeed, the microsatellites are located on different chromosomes and are highly polymorphic, can be easily amplified by PCR, and their analysis allows us to define a DNA profile with which we can typify an individual (as it is specific for each individual) (35). This is possible since microsatellite loci differ in each person in terms of the number of repetitions in sequence homologues between individuals.

If compared to other DNA techniques, such as VNTR, they are characterized by higher sensitivity and, being highly polymorphic, they have great powers of discrimination (32). 

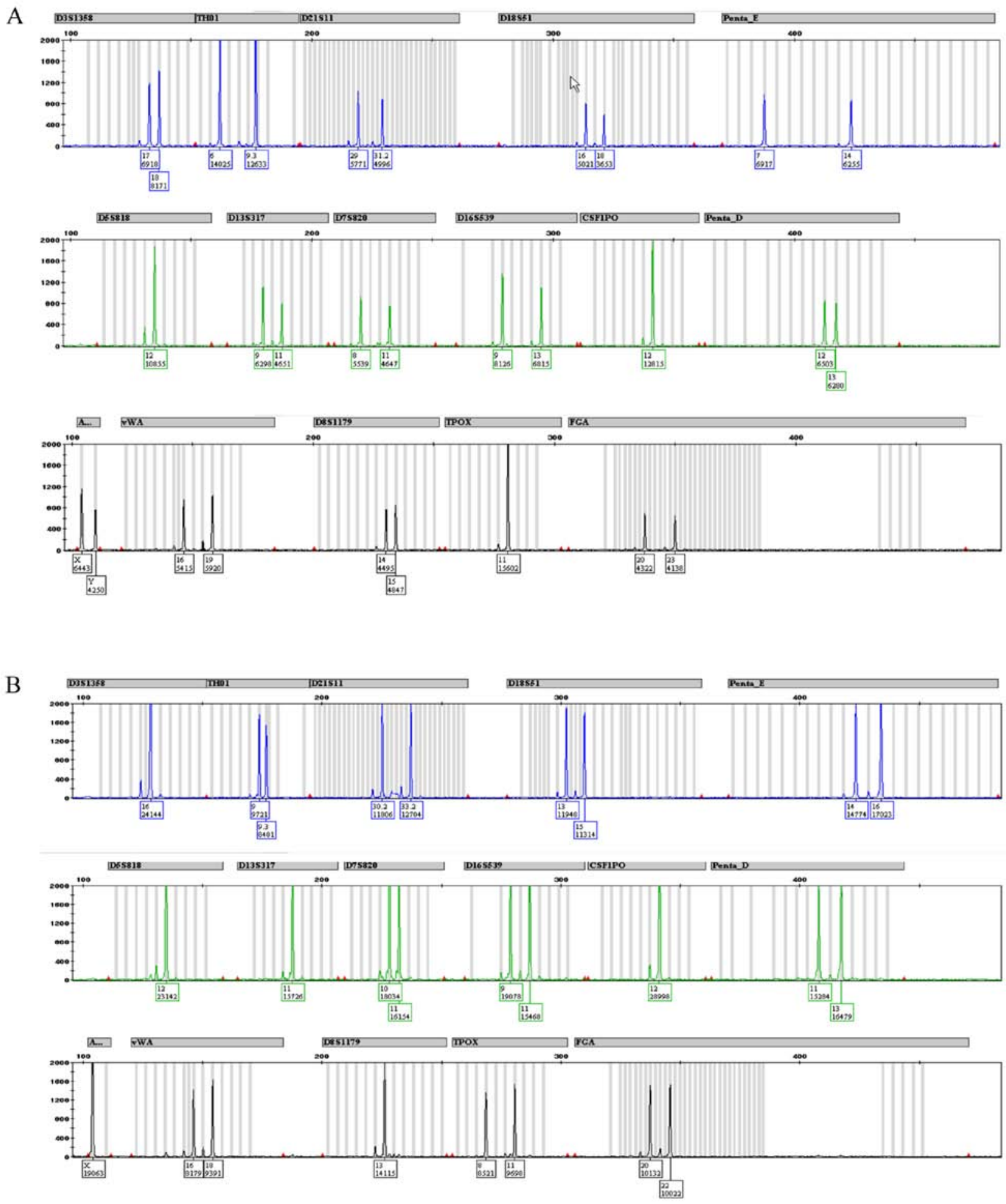

Figure 5. Typical human short tandem repeats (STR) profiles: typical male (A) and female (B) human STR profiles.

STR analysis is easily multiplexed, and thus several loci can be analyzed at the same time; over the years, several combinations of STR have been analyzed and the number of loci examined has gradually increased (32); usually, the gender identification-marker Amelogenin is also added to other specific STR to assess whether the sample originated in a male or female (25). Considering such STR features, it is not surprising that they have become essential in several fields ranging from the characterization of disease genes, population genetics studies, human identification and pater- nity testing (35). Even in research, the STR profiling of cells is highly recommended, most of all for cell identification (25); indeed, STR profiling has quickly become the international reference standard to identify cell lines and is currently the most widely used method (19-22,36).

However, that said, it is interesting to point out that, in the same cell lines, continuous passage in the culture causes a genetic drift and, particularly in cancer cells, genetic alterations (such as loss of heterozygosis, allelic deletions or instability) induce changes in STR profiles $(21,37,38)$; alterations of DNA 
A

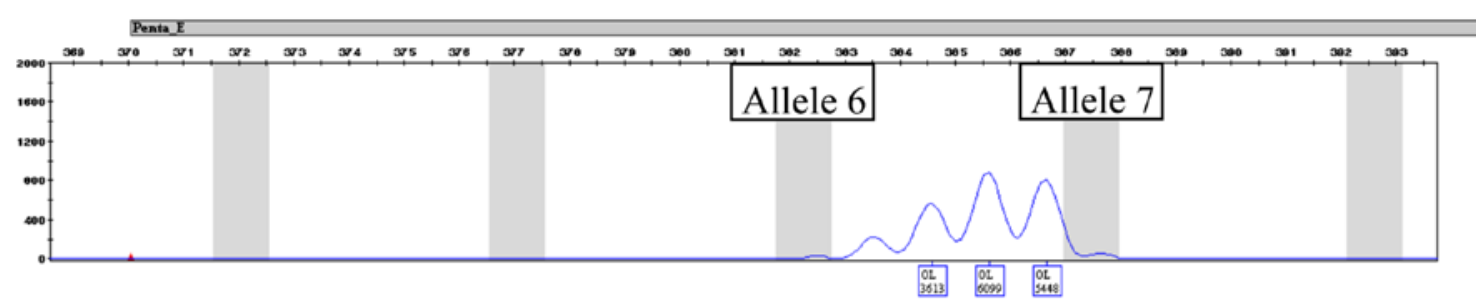

B
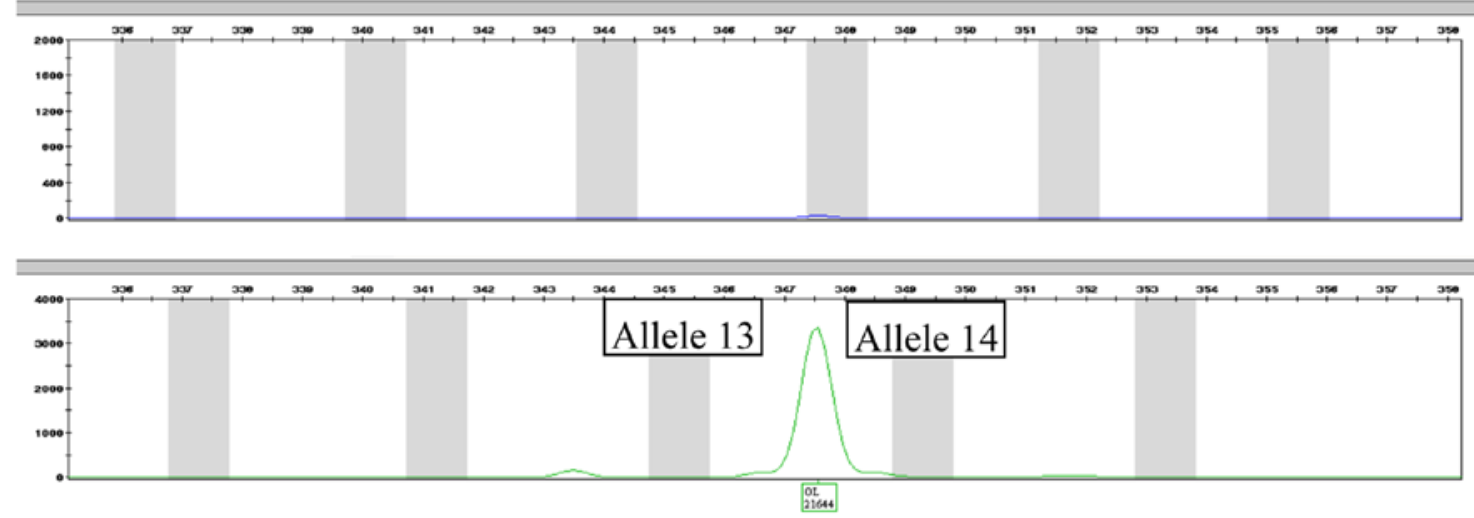

$\mathrm{C}$
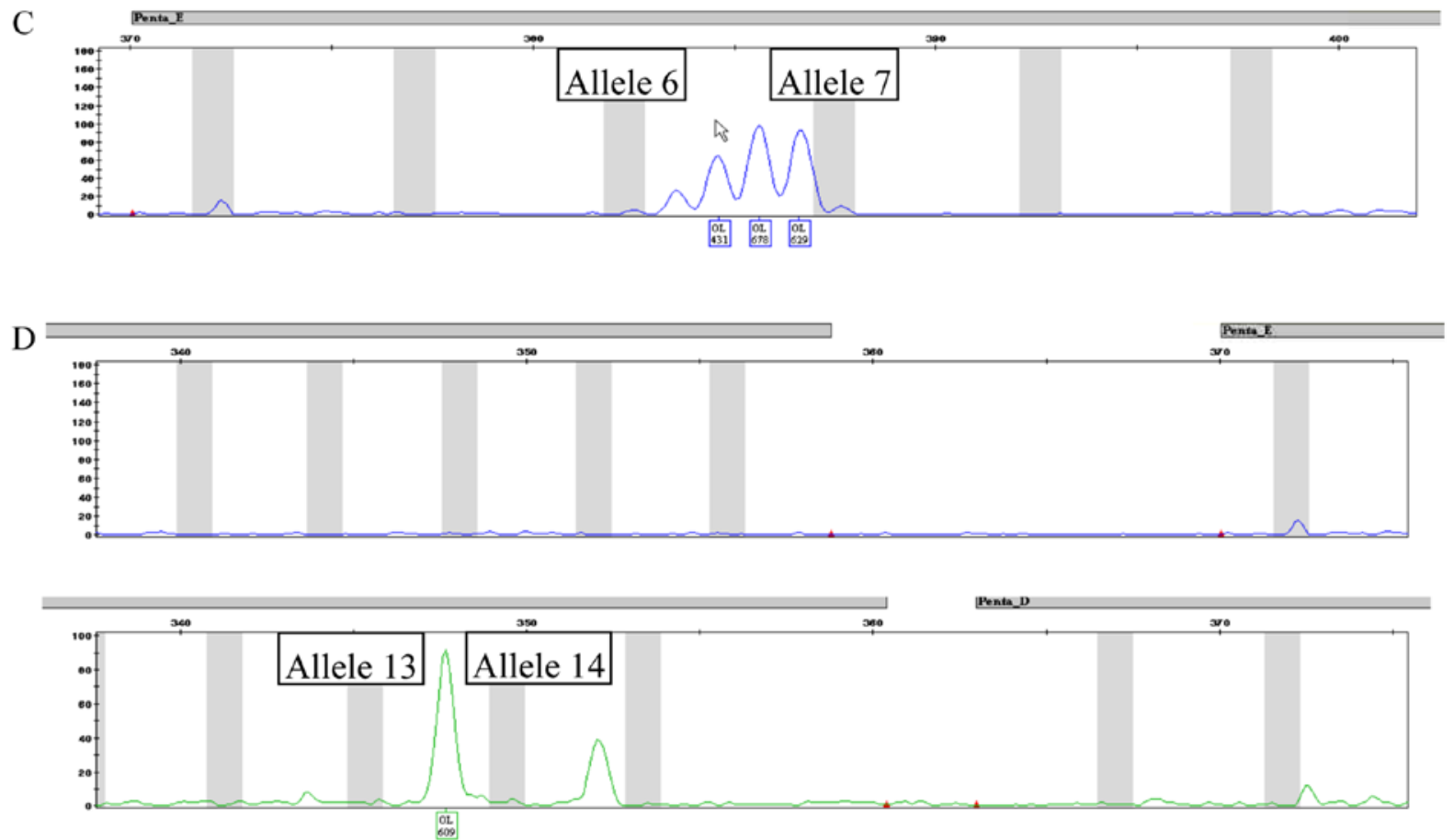

Figure 6. Details of CABA I alleles: CABA I cells at 18th passage, details of (A) Penta E and (B) CSF1PO alleles. CABA I cells at 38th passage, details of (C) Penta E and (D) CSF1PO alleles.

fingerprinting profiles have been already reported for some established hematopoietic cancer cell lines, during long-term culture; alterations were so drastic that DNA fingerprinting profiles of cultured cell lines and parental cells also differed considerably (23).

In the present study, we reported on the genetic characterization of the CABA I cell line, an ovarian cancer cell line of epithelial origin which was established in the 1997 from ascitic fluid obtained from a patient with papillary adenocarcinoma of the ovaries prior to drug treatment (10). Just after isolation, CABA I cells (at the 18th passage) were first roughly analyzed by means of classical cytogenetic techniques (GTG-banding) alone (10). Subsequently, in the present study, a more in-depth genetic characterization was performed, involving studying the STR profile and molecular cytogenetic data from the 18th passage. Moreover, in order to verify the in vitro long term culture effects on the genetic features of the CABA I cell line, these examinations were repeated on cells at the 38th passage. It was not possible to recover the donor's original tissue, and initial passage stocks of CABA I cells are no longer available for comparison, and thus we compared 38th with an 18th passage, which is the most precocious we have. This 
passage is the same as that used for original analyses, which were undertaken as soon as the cell line was established years ago (10).

In the present study, STR profiles were analyzed by means of the PowerPlex 16 HS kit. The amplification PCR kit PowerPlex $16 \mathrm{HS}$ is a multiplex STR test that co-amplifies in a single PCR all the 13 loci (D18S51, D21S11, TH01, D3S1358, FGA, TPOX, D8S1179, vWA, CSF1PO, D16S539, D7S820, D13S317 and D5S818) required from the Combined DNA Index System (CODIS) for individual identification in the USA (39), the gender-specific marker Amelogenin, and two additional low-stutter and highly discriminating pentanucleotide STR loci, Penta E and Penta D. It is evident from the comparison with a normal STR profile (as shown in Fig. 5) that the CABA I cell line STR profile is not complete, showing only the loci D7, FGA and Amelogenin (this latter confirming that it is female DNA). One possible explanation is that the primers find only three unchanged attack sites (allowing for amplification of only the three corresponding loci) while other primers no longer recognize the complementary sequences due to the DNA changes, as highlighted by our cytogenetic analysis.

Even if the CABA I cell line exhibits an anomalous STR profile that does not fully adjust the criteria currently used for the identification of human cells, nevertheless chromosome analysis confirmed the human origin of this cell line since we noted the presence of certain normal chromosome, such as 8 , 12, 14, 19 and $X$.

The obtained data suggest that the particular karyotypic complexity of the CABA I cell line, as shown by the results from chromosomal analysis at the 18th passage, are due to development following a progression scheme akin to that described in a case of primary ovarian cancer (40): i) genomic instability with the onset of few chromosomal structural aberrations; ii) polyploidization; and iii) massive structural changes and loss of individual chromosomes. According to this scheme, markers M6, M10, M16, M24, M25, M33 and M34 (present in duplicate) as well as nullisomy on 6q25-27 are likely to have arisen early in tumor progression.

The comparative cytogenetic analysis of the two different passages in CABA I cell line undertaken in the present study has demonstrated some features of evolutive behavior in neoplastic cells, corroborating our hypothesis on the developmental outline in neoplastic cells, which is essentially similar in the cell line and primary tumors. In fact, the occurrence of non-reciprocal translocations between some markers (M3, M31, M34 and M39) increases the complexity of this karyotype, and appears to be a way of reducing 'step-by-step' the number of double markers and the total number of chromosomes, and masks the initial 'phase' of polyploidization.

In addition, the cytogenetic balance of the 18th as well as the 38th passage outlines that certain regions, as previously reported (41), are preferentially lost (i.e., 6qter), whereas others, such as $12 \mathrm{q}$, are over-represented. In particular, the over-representation of $12 \mathrm{q}$, previously described as an ovarian cancer marker, in CABA I demonstrates a progressive achievement (M43), thus representing a secondary change in the evolution of this type of tumor.

Previous imbalance of $15 q 11-15$ and 7 p11-13 regions also seems to be confirmed, while 17 p gains are sensibly reduced to a loss of M32.
Finally, even if CABA I exhibited a noteworthy chromosomal instability, we have observed after 20 passages a substantially consistent pool of cytogenetic aberrations, demonstrating that recognized chromosomal aberrations are quite stable and probably present in vivo, too.

All these findings suggest that cytogenetic studies on cell lines are as reliable as those on primary tumors and, thus, represent a useful means of identifying the chromosome regions potentially responsible for tumor progression and evolution.

In conclusion, our data suggest that CABA I exhibits in vitro cellular behavior which overlaps with that observed in primary tumors where genome instability promotes the onset of chromosomal rearrangements that, conferring a proliferative advantage, characterize certain developmental stages and progression of the tumor itself. Such features make the CABA I cell line a suitable candidate to analyze, in vitro, the genetic evolution of ovarian cancer cells in vivo.

In addition, it is possible that karyotypic complexity resulting from many in vivo accumulated aberrations also significantly altered the STR pattern, so that of the 16 loci generally used in human STR profiles only 3 were properly detectable in CABA I cells; nonetheless, this molecular situation remains stable within 20 passages and represents another characteristic of the CABA cell line which is useful for checking its identity. A possible explanation for the anomalous STR profile, if compared to normal cells, can be found in the failure of remaining STR loci to amplify; the latter may be due to mutations and karyotypic rearrangements accumulated during in vitro culture, which implies that primers can no longer properly hybridize, not allowing, consequently, the amplification of corresponding fragments.

Moreover, it is evident that, even if it is widely used to identify and characterize cell lines, the STR profile alone is not sufficient as a marker for particular cell lines.

\section{References}

1. Chan JK, Cheung MK, Husain A, Teng NN, West D, Whittemore AS, Berek JS and Osann K: Patterns and progress in ovarian cancer over 14 years. Obstet Gynecol 108: 521-528, 2006.

2. Lutz AM, Willmann JK, Drescher CW, Ray P, Cochran FV, Urban N and Gambhir SS: Early diagnosis of ovarian carcinoma: is a solution in sight? Radiology 259: 329-345, 2011.

3. Goff BA, Mandel LS, Drescher CW, Urban N, Gough S, Schurman KM, Patras J, Mahony BS and Andersen MR: Development of an ovarian cancer symptom index: possibilities for earlier detection. Cancer 109: 221-227, 2007.

4. Ozols R, Rubin S, Thomas G and Robboy S: Epithelial ovarian cancer. In: Hoskins W, Perez CA, Young RC, Barakat RR, Markman $M$ and Randall $\mathrm{ME}$ (eds). Principles and Practice of Gynecologic Oncology. 4th edition. Lippincott Williams \& Wilkins, Philadelphia, pp895-987, 2005.

5. Hamilton TC, Young RC, McKoy WM, Grotzinger KR, Green JA, Chu EW, Whang-Peng J, Rogan AM, Green WR and Ozols RF: Characterization of a human ovarian carcinoma cell line (NIH:OVCAR-3) with androgen and estrogen receptors. Cancer Res 43: 5379-5389, 1983.

6. Fogh J, Wright WC and Loveless JD: Absence of HeLa cell contamination in 169 cell lines derived from human tumors. J Natl Cancer Inst 58: 209-214, 1977.

7. Hamilton TC, Young RC and Ozols RF: Experimental model systems of ovarian cancer: applications to the design and evaluation of new treatment approaches. Semin Oncol 11: 285-298, 1984.

8. Bénard J, Da Silva J, De Blois MC, Boyer P, Duvillard P, Chiric E and Riou G: Characterization of a human ovarian adenocarcinoma line, IGROV1, in tissue culture and in nude mice. Cancer Res 45: 4970-4979, 1985. 
9. Wilson AP: Characterization of a cell line derived from the ascites of a patient with papillary serous cystadenocarcinoma of the ovary. J Natl Cancer Inst 72: 513-521, 1984.

10. Dolo V, Ginestra A, Violini S, Miotti S, Festuccia C, Miceli D, Migliavacca M, Rinaudo C, Romano FM, Brisdelli F, et al: Ultrastructural and phenotypic characterization of CABA I, a new human ovarian cancer cell line. Oncol Res 9: 129-138, 1997.

11. Dolo V, D’Ascenzo S, Violini S, Pompucci L, Festuccia C, Ginestra A, Vittorelli ML, Canevari S and Pavan A: Matrixdegrading proteinases are shed in membrane vesicles by ovarian cancer cells in vivo and in vitro. Clin Exp Metastasis 17: 131-140, 1999.

12. Ferretti A, D'Ascenzo S, Knijn A, Iorio E, Dolo V, Pavan A and Podo F: Detection of polyol accumulation in a new ovarian carcinoma cell line, CABA I: A(1)H NMR study. Br J Cancer 86 : 1180-1187, 2002.

13. Violini S, D'Ascenzo S, Bagnoli M, Millimaggi D, Miotti S, Canevari S, Pavan A and Dolo V: Induction of a multifactorial resistance phenotype by high paclitaxel selective pressure in a human ovarian carcinoma cell line. J Exp Clin Cancer Res 23 . 83-91, 2004.

14. Dolo V, D'Ascenzo S, Giusti I, Millimaggi D, Taraboletti G and Pavan A: Shedding of membrane vesicles by tumor and endothelial cells. Ital J Anat Embryol 110 (Suppl 1): 127-133, 2005.

15. Prinetti A, Millimaggi D, D'Áscenzo S, Clarkson M, Bettiga A, Chigorno V, Sonnino S, Pavan A and Dolo V: Lack of ceramide generation and altered sphingolipid composition are associated with drug resistance in human ovarian carcinoma cells. Biochem J 395: 311-318, 2006.

16. Taraboletti G, D'Ascenzo S, Giusti I, Marchetti D, Borsotti P, Millimaggi D, Giavazzi R, Pavan A and Dolo V: Bioavailability of VEGF in tumor-shed vesicles depends on vesicle burst induced by acidic $\mathrm{pH}$. Neoplasia 8: 96-103, 2006.

17. Millimaggi D, Mari M, D' Ascenzo S, Giusti I, Pavan A and Dolo V: Vasculogenic mimicry of human ovarian cancer cells: role of CD147. Int J Oncol 35: 1423-1428, 2009.

18. Giusti I, D'Ascenzo S, Millimaggi D, Taraboletti G, Carta G, Franceschini N, Pavan A and Dolo V: Cathepsin B mediates the $\mathrm{pH}$-dependent proinvasive activity of tumor-shed microvesicles. Neoplasia 10: 481-488, 2008.

19. Masters JR, Thomson JA, Daly-Burns B, Reid YA, Dirks WG, Packer P, Toji LH, Ohno T, Tanabe H, Arlett CF, et al: Short tandem repeat profiling provides an international reference standard for human cell lines. Proc Natl Acad Sci USA 98: 8012-8017, 2001.

20. Barallon R, Bauer SR, Butler J, Capes-Davis A, Dirks WG, Elmore E, Furtado M, Kline MC, Kohara A, Los GV, et al Recommendation of short tandem repeat profiling for authenticating human cell lines, stem cells, and tissues. In Vitro Cell Dev Biol Anim 46: 727-732, 2010.

21. Capes-Davis A, Reid YA, Kline MC, Storts DR, Strauss E, Dirks WG, Drexler HG, MacLeod RA, Sykes G, Kohara A, et al: Match criteria for human cell line authentication: where do we draw the line? Int J Cancer 132: 2510-2519, 2013.

22. Masters JRW; American Type Culture Collection Standards Development Organization Workgroup ASN-0002: Cell line misidentification: the beginning of the end. Nat Rev Cancer 10 : 441-448, 2010

23. Verma R and Babu A: Human Chromosomes: Principles \& Techniques. 2nd edition. McGraw-Hill,Inc., New York, NY, 1995

24. Parson W, Kirchebner R, Mühlmann R, Renner K, Kofler A, Schmidt S and Kofler R: Cancer cell line identification by short tandem repeat profiling: power and limitations. FASEB J 19: 434-436, 2005

25. Azari S, Ahmadi N, Tehrani MJ and Shokri F: Profiling and authentication of human cell lines using short tandem repeat (STR) loci: report from the National Cell Bank of Iran. Biologicals 35: 195-202, 2007.
26. Steube KG, Grunicke D and Drexler HG: Isoenzyme analysis as a rapid method for the examination of the species identity of cell cultures. In Vitro Cell Dev Biol Anim 31: 115-119, 1995.

27. O'Toole CM, Povey S, Hepburn P and Franks LM: Identity of some human bladder cancer cell lines. Nature 301: 429-430, 1983.

28. Gown AM and Vogel AM: Monoclonal antibodies to human intermediate filament proteins. III. Analysis of tumors. Am J Clin Pathol 84: 413-424, 1985.

29. Quentmeier H, Osborn M, Reinhardt J, Zaborski M and Drexler HG: Immunocytochemical analysis of cell lines derived from solid tumors. J Histochem Cytochem 49: 1369-1378, 2001.

30. Kaighn ME, Narayan KS, Ohnuki Y, Lechner JF and Jones LW: Establishment and characterization of a human prostatic carcinoma cell line (PC-3). Invest Urol 17: 16-23, 1979.

31. Gilbert DA, Reid YA, Gail MH, Pee D, White C, Hay RJ and O'Brien SJ: Application of DNA fingerprints for cell-line individualization. Am J Hum Genet 47: 499-514, 1990.

32. Thompson R, Zoppis S and McCord B: An overview of DNA typing methods for human identification: past, present, and future. Methods Mol Biol 830: 3-16, 2012.

33. Silva LM, Montes de Oca H, Diniz CR and Fortes-Dias CL: Fingerprinting of cell lines by directed amplification of minisatellite-region DNA (DAMD). Braz J Med Biol Res 34: 1405-1410, 2001.

34. Chambers GK and MacAvoy ES: Microsatellites: consensus and controversy. Comp Biochem Physiol B Biochem Mol Biol 126: 455-476, 2000.

35. Yan R, Ottenbreit M, Hukku B, Mally M, Chou S and Kaplan J: DNA fingerprinting of human cell lines using PCR amplification of fragment length polymorphisms. In Vitro Cell Dev Biol Anim 32: 656-662, 1996.

36. Korch C, Spillman MA, Jackson TA, Jacobsen BM, Murphy SK, Lessey BA, Jordan VC and Bradford AP: DNA profiling analysis of endometrial and ovarian cell lines reveals misidentification, redundancy and contamination. Gynecol Oncol 127: 241-248, 2012.

37. Poetsch M, Petersmann A, Woenckhaus C, Protzel C, Dittberner T, Lignitz E and Kleist B: Evaluation of allelic alterations in short tandem repeats in different kinds of solid tumors - possible pitfalls in forensic casework. Forensic Sci Int 145: 1-6, 2004.

38. Vauhkonen H, Hedman M, Vauhkonen M, Kataja M, Sipponen P and Sajantila A: Evaluation of gastrointestinal gastrointestinal cancer tissues as a source of genetic information for forensic investigations by using STRs. Forensic Sci Int 139: 159-167, 2004.

39. Ensenberger MG, Thompson J, Hill B, Homick K, Kearney V, Mayntz-Press KA, Mazur P, McGuckian A, Myers J, Raley K, et al: Developmental validation of the PowerPlex 16 HS System: an improved 16-locus fluorescent STR multiplex. Forensic Sci Int Genet 4: 257-264, 2010.

40. Pejovic T, Heim S, Orndal C, Jin YS, Mandahl N, Willén H and Mitelman F: Simple numerical chromosome aberrations in well-differentiated malignant epithelial tumors. Cancer Genet Cytogenet 49: 95-101, 1990.

41. Tibiletti MG, Bernasconi B, Furlan D, Bressan P, Cerutti R, Facco C, Franchi M, Riva C, Cinquetti R, Capella C and Taramelli R: Chromosome 6 abnormalities in ovarian surface epithelial tumors of borderline malignancy suggest a genetic continuum in the progression model of ovarian neoplasms. Clin Cancer Res 7: 3404-3409, 2001. 